\title{
OPEN Phytochemical Screening, Spectrum Profile of Functional Groups, and Effervescent Formulation of Kepok Banana Peels Stem Extract
}

Robby Candra Purnamaa ${ }^{a^{*}}$, Annisa Primadiamanti ${ }^{\mathrm{b}}$

Abstract. Kepok banana plants contain secondary metabolites such as tannins and flavonoids. Tannins and flavonoids have various properties for human health. Research has been carried out to identify secondary metabolite compounds (tannins, flavonoids, and saponins) by using the phytochemical screening method to see the functional group profile contained in the extract of kepok banana stem waste. Kepok banana stem waste was extracted in $96 \%$ ethanol, then evaporated and screened phytochemically. This extract was used to prepare effervescently. Screening results showed that tannin and flavonoids were identified by the appearance of the following color black-green and dark red, respectively. Meanwhile, saponins were negative because the foam formed had a height of $0.3 \mathrm{~cm}$ and did not meet the saponins' positive requirements (1-3 cm high foam and stable for 5 minutes). Identification of functional groups in the extract of kepok banana stem waste using Fouriertransform Infrared Spectroscopy (FTIR) showed that C-C stretching in the area $2927.24 \mathrm{~cm}^{-1}, \mathrm{O}-\mathrm{H}$ stretching in the $3423.87 \mathrm{~cm}^{-1}$ area, $\mathrm{C}=\mathrm{O}$ stretching in the $1648.87 \mathrm{~cm}^{-1}$ area. Also appeared bending $\mathrm{CH}_{2}$ in the region of $1421.45 \mathrm{~cm}^{-1}$, and $\mathrm{C}-\mathrm{C}$ in the area of $1149.98 \mathrm{~cm}^{-1}$. The characteristics of three different formulas $(A, B$, and $C)$ of effervescent have been investigated: the moisture content of $2.51 \% ; 2.55 \%$, and $2.52 \%$, respectively. Then, flow rate of $8.81 \mathrm{~g} / \mathrm{s}$; $8.83 \mathrm{~g} / \mathrm{s}$; and $8.82 \mathrm{~g} / \mathrm{s}$, compressibility of $14.5 \% ; 14.4 \%$; and $14.5 \%$, and a pH of $5.97 ; 5.98$; and 5.97 respectively. All parameters are eligible.

Keywords: banana stems, effervescent, flavonoids, functional groups, and tannins

a,b University of Malahayati, Bandar Lampung, 35158, Indonesia Correspondence and requests for materials should be addressed to Robby Chandra Purnama (email: robby_candra@malahayati.ac.id) 


\section{Introduction}

Banana is one of the plantation commodities in Indonesia. The utilization of banana plants had been done since ancient times, such as its weevils, leaves, and especially the banana itself. The banana stalk is one part of the banana plant that has not been used maximally and is usually just thrown away.

A study showed that banana plants have antibacterial materials, namely tannins, flavonoids, alkaloids, and steroids [1]. These compounds are included in secondary metabolites with many benefits, especially for human health [2].

Based on the research above, the researcher intends to use banana stem waste to be used as a product for health benefits by first looking at the content of secondary metabolite compounds that may still be in the banana stem waste. The compounds to be studied include tannins, flavonoids, and saponins and see the functional group profile in the extract.

Flavonoids are compounds found in plants as mixtures and very rarely in the single compound form [3]. Usually in the form of sugar, namely as a glycosal and flavonoid aglicon. Flavonoid contains a conjugated aromatic system.

Tannins are water-soluble phenolic compounds weighing 500-3000 mg equivalent of gallic acid, giving a general reaction to phenolic compounds [4]. Tannins form complexes not only with alkaloids and proteins but also with polysaccharides. Tannins are complex compounds. Usually, a mixture of polyphenols does not crystallize and only polyphenol polymerizations.

Saponins vary structure, physical properties and biological effects compounds in the form of glycons widely distributed in higher plants and some marine animals. Saponins are steroid glycons or triterpene compounds found in various plants. Saponins have a characteristic form of foam so that when it reacts with water, it will form foam that can last a long time. Saponins are readily soluble in water and insoluble in ether [5]-[7].

Then for the utilization of banana stem waste, the extract was formulated into an effervescent powder. The effervescent powder is coarse to a very coarse powder, and contains medicinal elements in a dry mixture, usually consisting of sodium bicarbonate, citric acid, and tartric acid. When water was added, the acid and base reacted to free carbon dioxide to produce foam [4].

Effervescent powder was chosen because, in addition to forming a dosage formulation that could be beneficial for health, effervescent also gives a fresh effect when consumed. The formulation was made with various uses of lactose to measure the level of sweetness.

\section{Experimental}

\section{Tools and Materials}

The equipment used includes erlenmeyer, stir rod, gloves, spatula, test tube, rotary evaporator, dropper pipette, petri cloud, autoclave, laminar airflow, spirit lamp, capillary pipette, IR spectrophotometer, oven, $\mathrm{pH}$ meter, and plate reader. While the materials used were Kepok banana stem, $96 \%$ ethanol, $10 \% \mathrm{NaOH}$, distilled water, $\mathrm{n}$ hexane, ethyl acetate, methanol, reagent $\mathrm{FeCl}_{3}, 70 \%$ alcohol, lactose, fruit flavor, aspartame, citric acid, tartaric acid, sodium bicarbonate, $\alpha$ - glucosidase, DMSO, sodium carbonate, TLC plate, paper, filter, tissue, aluminum foil.

\section{Kepok Banana Stem Extraction}

The maceration method extract from the kepok banana stem [8]-[10]. Kepok banana stems were taken $10 \mathrm{~cm}$, washed, cut into small pieces, dried at room temperature, then made into powder. The dry powder simplicia was macerated using ethanol solvent $96 \%$ to $1 \mathrm{~cm}$ above the kepok banana stem powder for 24 hours, then filtered and the precipitate was macerated again with $96 \%$ ethanol. This procedure was repeated until all of the metabolites have been extracted. All 96\% ethanol extracts were combined and evaporated using a rotary vacuum evaporator until dry, then weighed, and the yield was calculated. 


\section{Phytochemical Test of Kepok Banana Stem Extract}

The phytochemical test is a test conducted to identify the content of metabolite compounds in kepok banana stems, namely flavonoids, tannins, and saponins. Identification of flavonoids using $10 \%$ $\mathrm{NaOH}$ was added to the ethanol extract obtained using the maceration method, then added 2 drops of $10 \% \mathrm{NaOH}$ [11]. A yellow-orange-red color change indicated the presence of flavonoids. Saponin identification (foam test) was carried out by simplicia banana stems added with distilled water so that all parts were immersed and boiled for 2 minutes. After that, it cooled and shook vigorously. The emergence of a stable foam indicated the presence of saponins. Identification of tannins was carried out by diluting the extract of the kepok banana stem (Musa paradisiacal L) in solvent (n-hexane, ethyl acetate, and methanol), then pipetting into drop plate porcelain and adding $\mathrm{FeCl}_{3}$ reagent. The formation of a white precipitate indicated a positive result.

\section{Analysis Using an IR Spectrophotometer}

Peptide compound samples was pressed on $\mathrm{KBr}$ pellets with a sample ratio of $1: 100 \mathrm{KBr}$. The background used is pure $\mathrm{KBr}$ pellets. The spectrum was recorded in the transmittance mode at a wavenumber $4000-400 \mathrm{~cm}-1$.

\section{Effervescent Powder Preparation}

Citric acid and tartric acid crystal were crushed to get powders and sieved using No. 16, then dried in the oven at $\pm 50^{\circ} \mathrm{C}$ for 30 minutes (mixture 1). The dried extract was sprayed with sufficient flavor, after that was stirred until homogeneous, then sieved with a No.16 sieve and stored in a container ( $\operatorname{mix} 2$ ). Other ingredients, namely: lactose, aspartame, and sodium bicarbonate, were mixed and stirred until homogeneous, then sieved with No. 16. The Powder obtained was dried in an oven at $\pm 50^{\circ} \mathrm{C}$ for 30 minutes (mix 3 ). The dried mixture of 1,2 , and 3 was stirred until homogeneous, sieved with a No.40 sieve, so that become an effervescent powder, then stored in a desiccator [1], [12].

\section{Effervescent powder analysis}

Physical and chemical properties test of the effervescent powder (test moisture content, flow rate, compressibility, dissolving time, and $\mathrm{pH}$ of the solution) had been investigated.

\section{Results and Discussion}

Results of Phytochemical Screening of Kepok Banana Stem Extract presented in Table 1. This research was conducted to determine the content of secondary metabolite compounds that may still be present in banana stem waste. Banana stem waste samples were obtained in the home industry yard in Punggur area, Central Lampung. The kepok banana stem used is a banana stem that has been harvested from the fruit.

Table 1. Phytochemical Screening of Kepok Banana Stem Extract

\begin{tabular}{lll}
\hline \multicolumn{1}{c}{ Phytochemical Test } & \multicolumn{1}{c}{ Results } & \multicolumn{1}{c}{ Conclusions } \\
\hline Saponins & Formed foam as high as $0.3 \mathrm{~cm}$ & - \\
& for 10 minutes & \\
Tannins & Coloured greenish black & + \\
Flavonoids & Coloured dark red & + \\
\hline
\end{tabular}

The maceration method was used to extract Kepok banana stems, was classified as a cold extraction process so that the extraction results were good and prevent chemical damage to the sample due to heating [3], [13]. The principle of maceration is that chemical compounds with the same properties as the solvent will be attracted to and dissolved in the solvent so that certain chemical compounds can be separated. The solvent used in this method was $96 \%$ alcohol because its selectivity only attracts the desired nutritious substances, has good absorption, is not overgrown with fungus, volatile, and gets a viscous extract faster than $70 \%$ ethanol solvent [9]. 
Then samples were concentrated with a rotary evaporator until a thick extract was obtained.

After that, the effervescent powder preparation process was carried out with 3 formulations (see Table 2 ) and modified some of the additive components [11]. Formulation A was given more lactose and less sodium bicarbonate than formulation $\mathrm{B}$ and formulation $\mathrm{C}$. The formulation modification's objective was to find the best formulation to produce an effervescent powder that conforms to the requirements of effervescent powder testing [14]. The testing parameters for effervescent powders such as physical and chemical properties of the powder (moisture content test, flow rate, compressibility, solubility time, and solution $\mathrm{pH}$ ) [15]-[17].

Table 2. Formulation of effervescent powder

\begin{tabular}{lccc}
\hline \multirow{2}{*}{ Material } & \multicolumn{3}{c}{ Formula } \\
\cline { 2 - 4 } & A & B & C \\
\hline $\begin{array}{l}\text { Kapok banana stem } \\
\text { extract }\end{array}$ & $25 \mathrm{~g}$ & $25 \mathrm{~g}$ & $25 \mathrm{~g}$ \\
Lactose & $24 \mathrm{~g}$ & $19 \mathrm{~g}$ & $14 \mathrm{~g}$ \\
Fruit Taste & $\mathrm{Qs}$ & Qs & Qs \\
Aspartame & $1 \mathrm{~g}$ & $1 \mathrm{~g}$ & $1 \mathrm{~g}$ \\
Citric Acid & $9,5 \mathrm{~g}$ & $10,45 \mathrm{~g}$ & $11,4 \mathrm{~g}$ \\
Tartric acid & $13,5 \mathrm{~g}$ & $14,85 \mathrm{~g}$ & $16,2 \mathrm{~g}$ \\
Sodium bicarbonate & $27 \mathrm{~g}$ & $29,7 \mathrm{~g}$ & $32,4 \mathrm{~g}$ \\
\hline
\end{tabular}

Organoleptic tests were carried out by observing the smell, consistency, and color of effervescent powder preparations (see Table 3) [2], [18]. Rrganoleptic test is a way of testing using the human senses as the main tool to assess the quality of powder. Good powder preparation is in the form of a solid crystal powder and does not become thick.
Organoleptic test of color and odor of the effervescent powder formulation of Kepok banana stems has a distinctive banana odor and is also white. Meanwhile, the homogeneity test was used No.40 sieve to obtain a uniform powder size so that the powder became homogeneous [10], [12], [19].

Table 3. Organoleptic Test

\begin{tabular}{|c|c|c|c|}
\hline \multirow[t]{2}{*}{ Formulations } & \multicolumn{3}{|c|}{ Organoleptic Test } \\
\hline & Odor & Consistency & Color \\
\hline$A$ & $\begin{array}{l}\text { Slightly flavorful typical } \\
\text { of Kepok banana }\end{array}$ & Round powder, crystals & White \\
\hline $\mathrm{B}$ & $\begin{array}{l}\text { Slightly flavorful typical } \\
\text { of Kepok banana }\end{array}$ & Round powder, crystals & White \\
\hline C & $\begin{array}{l}\text { Slightly flavorful typical } \\
\text { of Kepok banana }\end{array}$ & Round powder, crystals & White \\
\hline $\begin{array}{l}\text { extract of the Kepok } \\
\text { banana stem }\end{array}$ & Banana scented & Concentrated liquid & Chocolate \\
\hline
\end{tabular}


Based on the phytochemical screening results on an extract of the Kepok banana stem in Table 1, three compounds were 3 compounds identified: saponins, tannins, and flavonoids. From the test results, the extract showed positive results for tannins and flavonoids, which had greenish-black color and dark red color, respectively. Meanwhile, the results were negative for saponins because although foam was formed, the foam was only $0.3 \mathrm{~mm}$ high and under $1 \mathrm{~cm}$ [3].

The sample was identified containing functional groups of the C-C stretching in $2927.24 \mathrm{~cm}^{-}$ 1 , O- $\mathrm{H}$ stretching in the $3423.87 \mathrm{~cm}^{-1}$ area, $\mathrm{C}=\mathrm{O}$ stretching appeared at $1648.87 \mathrm{~cm}^{-1}$, bending $\mathrm{CH}_{2}$ in the area of $1421.45 \mathrm{~cm}^{-1}$, and C-C appeared at $1149.98 \mathrm{~cm}^{-1}$.

Effervescent powder analysis showed that the moisture content obtained for formulations $A, B$, and $C$ was $2.51 \% ; 2.55 \%$, and $2.52 \%$, respectively. Moisture testing was performed using a measuring instrument of moisture meter. Meanwhile, the requirement for the water content of effervescent powder is less than $5 \%$, so that all the moisture content of the three formulations meets the requirements [15].

Table 4. Mositure Content Test

\begin{tabular}{ccc}
\hline Formulations & \multicolumn{2}{c}{ Mositure Content Test } \\
\cline { 2 - 3 } & Result & Standard \\
\hline A & $2.51 \%$ & $<5 \%$ \\
B & $2.55 \%$ & \\
C & $2.52 \%$ & \\
\hline
\end{tabular}

The flow rate of formulations $A, B$, and $C$ was $8.81 \mathrm{~g} / \mathrm{s} ; 8.83 \mathrm{~g} / \mathrm{s}$; and $8.82 \mathrm{~g} / \mathrm{s}$. These results indicated that the flow properties of the three formulations' effervescent powders still meet the requirements where the flow rate requirements of effervescent powders are 4-10 g/s and fall into the easy-to-flow category [20].

Table 5. Flow Rate Test

\begin{tabular}{ccc}
\hline Formulations & \multicolumn{2}{c}{ Flow Rate Test } \\
\cline { 2 - 3 } & Result & Standard \\
\hline A & $8.81 \mathrm{~g} / \mathrm{s}$ & \\
B & $8.83 \mathrm{~g} / \mathrm{s}$ & $4-10 \mathrm{~g} / \mathrm{s}$ \\
C & $8.82 \mathrm{~g} / \mathrm{s}$ & \\
\hline
\end{tabular}

The three formulations' $\mathrm{pH}$ was 5.97; 5.98; and 5.97, which were still close to the requirements, namely between 6-7. The water holding capacity of the effervescent powder starting from formulations A, B, and C, among others, was 0.354; 0.362; and $0.358 \mathrm{~g} / \mathrm{g}$ and still meet the requirements [4]-[8].

Table 6. pH Test

\begin{tabular}{ccc}
\hline Formulations & \multicolumn{2}{c}{ pH Test } \\
\cline { 2 - 3 } & Result & Standard \\
\hline A & 5.97 & $6-7 \mathrm{~g} / \mathrm{s}$ \\
B & 5.98 & \\
\cline { 2 - 3 }
\end{tabular}




\begin{tabular}{ccc}
\multicolumn{2}{c}{5.96} \\
\hline & Table 7. Water Holding Capacity \\
\cline { 2 - 3 } & Formulations & Water Holding Capacity \\
\cline { 2 - 2 } & Result \\
\hline A & $0.354 \mathrm{~g} / \mathrm{g}$ \\
B & $0.362 \mathrm{~g} / \mathrm{g}$ \\
C & $0.358 \mathrm{~g} / \mathrm{g}$ \\
\hline
\end{tabular}

For the compressibility test, the effervescent powder produced from formulations $\mathrm{A}, \mathrm{B}$, and $\mathrm{C}$, yielded $14.5 \%$; $14.4 \%$; and $14.5 \%$, which met the granule compressibility requirements, namely less than $20 \%$ [5] [21].

Table 8. Compressibility Test

\begin{tabular}{ccc}
\hline Formulations & \multicolumn{2}{c}{ Compressibility Test } \\
\cline { 2 - 3 } & Result & Standard \\
\hline A & $14.5 \%$ & \\
B & $14.4 \%$ & $<20 \%$ \\
C & $14.5 \%$ & \\
\hline
\end{tabular}

\section{Conclusion}

It was concluded that the Kepok banana waste contained two secondary metabolites in the banana stem waste, namely tannins and flavonoids. Meanwhile, saponin compounds were not found in kepok banana stem waste. The sample was identified containing functional groups of the $\mathrm{C}-\mathrm{C}$ stretching in $2927.24 \mathrm{~cm}^{-1}, \mathrm{O}-\mathrm{H}$ stretching in the $3423.87 \mathrm{~cm}^{-1}$ area, $\mathrm{C}=\mathrm{O}$ stretching appeared at $1648.87 \mathrm{~cm}^{-1}$, bending

\section{References}

[1] M. MARHAMAH and I. W. Putri, "Efektivitas Ekstrak Batang Pisang Kepok (Musa $x$ paradisiaca Linn.) Terhadap Pertumbuhan Bakteri Streptococcus pyogenes.," J. Anal. Kesehat., vol. 7, no. 1, p. 704, 2018.

[2] M. R.A and M. . Pincus, Henry's Clinical Diagnosis and Management by Laboratory Methods (21st ed). Saunders Elsevier, 2007.

[3] Y. Noviyanty, H. Hepiyansori, and B. R. Dewi, "Identifikasi dan Penetapan Kadar Senyawa Saponin Ekstrak Etanol Bunga Senggani (Melastoma malabathricum L) Metode Gravimetri," Ocean. Biomed. J., vol. 3, no. 1, p.
$\mathrm{CH}_{2}$ in the area of $1421.45 \mathrm{~cm}^{-1}$, and $\mathrm{C}-\mathrm{C}$ appeared at $1149.98 \mathrm{~cm}^{-1}$.

Furthermore, the effervescent powder characteristics met the requirements, so the effervescent powder dosage formulation made from the kepok banana stem waste's extract showed good results.

45, 2020.

[4] H. Ansel, Pengantar Bentuk Sediaan Farmasi. Alih bahasa Farida Ibrahim. Edisi 4. Jakarta: UI Press, 1989.

[5] M. E. Aulton, Pharmaceutics: The science of dosage form design. Edinburgh: Churchill Livingstone, 2012.

[6] L. Lachman and H. A. Liebermann, The Theory and practice of industrial pharmacy. New Delhi: CBS Publishers \& Distributors Pvt. Ltd, 2013.

[7] C. P.C, R. . Harvey, and D. . Ferrier, Lippincott's Illustrated Reviews: Biochemistry. Philadelphia: Lippincott Williams and Wilkins, 2005. 
[8] C. B, Pisang: Usaha Tani dan Penanganan Pasca Panen (Revisi Kedua). Yogyakarta: Kanisius, 2009.

[9] D. R, R. A, and A. M, "Banana Peel (Musa Paradisiaca): Can It be a Revolunationary Change in Periodontal Therapy ? A Review," Int. J. Sci. Res., vol. 5, no. 7, pp. 357-359, 2016.

[10] K. A. N and Marsusi, "Karakterisasi 20 kultivar pisang buah domestik (Musa paradisiaca) dari Banyuwangi Jawa Timur," EL-VIVO, vol. 2, no. 1, 2014.

[11] N. R. FARNSWORTH, "Biological and Phytochemical Screening of Plants," J. Pharm. Sci., vol. 55, no. 3, pp. 874-875, 1966.

[12] Kuswanto, Bertanam Pisang dan Cara Pemeliharaannya. Solo: CV. Deriko, 2007.

[13] Suyanti and A. Supriyadi, Pisang: Budidaya, Pengolahan, dan Prospek Pasar. Jakarta: Penebar Swadaya, 2008.

[14] USDA-NRCS, "The Plants Database. National Plant Data Center: Lousiana," 2003. .

[15] W. B.G, D. J.T, S. T.L, and D. C. V, Pharmacotherapy Handbook Ninth Edition. United States: Mc Graw Hill, 2015.

[16] V. K. Venkatesh, K. K. G, K. P., and K. S. R. S., "Antibacterial activity of ethanol extract of Musa paradisiaca cv. Puttabale and Musa acuminate cv. grand naine," Asian J. Pharm. Clin. Res., vol. 6, no. 2, pp. 169-172, 2013.

[17] S. D, J. B, and S. C, "A Review: Pharmacognostic studies and Pharmacological actions of Musa Paradisiaca," Int. J. Innov. Pharm. Res., vol. 2, no. 2, pp. 122-125, 2011.

[18] M. R. K, D. K. G, and V. W. R, Biokimia Harper Edisi 27, Diterjemahkan oleh Wulandari $N$. Jakarta: EGC, 2009.

[19] BPOM, Informatorium Obat Nasional Indonesia. Jakarta: Badan Pengawas Obat dan Makanan Republik Indonesia, 2009.

[20] B. K. Alldredge et al., Koda-Kimble and Young's applied therapeutics: The clinical use of drugs. United States: Wolters Kluwer Health Adis (ESP), 2013.

[21] M. R. Penn, J. J. Pauer, and J. R. Mihelcic, "Biochemical oxygen demand. Environmental and Ecological Chemistry," vol. II, pp. 278-297, 2009. 